\title{
Article \\ Contribution of Supportive Local Communities to Sustainable Event Tourism
}

\author{
Xiubai Li ${ }^{1}$, Jinok Susanna Kim ${ }^{2, *}$ and Timothy J. Lee ${ }^{3,4}$ \\ 1 School of History, Culture and Tourism, Guangxi Normal University, Guilin 541001, China; \\ lixiubai@gxnu.edu.cn \\ 2 Department of Airline Service, Sehan University, Dangjin 31746, Korea \\ 3 Faculty of Hospitality and Tourism Management, Macau University of Science and Technology, \\ Macao 999078, China; tilee@must.edu.mo \\ 4 Griffith Institute for Tourism, Griffith University, Nathan, QLD 4111, Australia; timothy.lee@griffith.edu.au \\ * Correspondence: s2924@sehan.ac.kr; Tel.: +82-41-359-6028
}

Citation: Li, X.; Kim, J.S.; Lee, T.J Contribution of Supportive Local Communities to Sustainable Event Tourism. Sustainability 2021, 13, 7853. https://doi.org/10.3390/su13147853

Academic Editor: J. Andres Coca-Stefaniak

Received: 11 June 2021

Accepted: 6 July 2021

Published: 14 July 2021

Publisher's Note: MDPI stays neutral with regard to jurisdictional claims in published maps and institutional affiliations.

Copyright: (c) 2021 by the authors. Licensee MDPI, Basel, Switzerland. This article is an open access article distributed under the terms and conditions of the Creative Commons Attribution (CC BY) license (https:// creativecommons.org/licenses/by/ $4.0 /)$.
Abstract: The importance of community attitude and participation for the success and sustainability of cultural festivals has been steadily increasing in recent years. The Chuncheon Puppet Festival $(\mathrm{CPF})$ is an international festival that has been held every year since 1989 in Chuncheon, Korea. The festival has several distinctive characteristics as a sustainable event because: (a) it maintains its single genre of puppet performances based on modern cultural art; (b) it is well-established as the festival for the local residents of Chuncheon City and is planned by local community residents and local small companies, not by government agencies or global large entrepreneurs; (c) it helps children to have an interesting cultural experience in the local environment; and (d) it is regularly hosted in August, an off-season for festivals in Korea that was chosen by residents as it is a school holiday season. However, there is still room for improvement to secure its place as a successful sustainable festival. The following might be considered: (i) increased exchange of human resources among the festival executive members, community groups, and the public staff in Chuncheon City; (ii) local residents should maintain full control of the festival; and (iii) a local cultural trust should be established by cultural art professionals, local resident organizations, puppet show professionals, and public agency staff. The CPF is a typical example of a successful sustainable festival with proactive and supportive community participation and a large number of volunteers that help to increase local competitiveness and sustainable local development. This case report delivers insightful lessons and messages to guide what needs to be preconditioned for local cultural festivals to be sustainable and successful for a long time in many destinations, where they can contribute as efficient catalysts for regional tourism development.

Keywords: local festival; community participation; sustainable event; local residents

\section{Introduction}

Community participation has become an umbrella term for a supposedly new genre of tourism development processes [1]. To propose a development strategy that is not participatory is now considered reactionary [2]. Thus, the major aspects of development, research, planning, implementation, and control of a tourism destination have been reoriented to make development more participatory [3]. Community participation is to design "development in such a way that intended beneficiaries are encouraged to take matters into their own hands, to participate in their own development through mobilizing their own resources, defining their own needs, and making their own decisions about how to meet their needs" [4] (p. 207). This implies that community participation as a development strategy is based on community resources, needs, and decisions [5]. Hence, the community is the main actor in the development process [6]. On the other hand, the concept of com- 
munity participation is also seen as a powerful tool to educate the community in rights, laws, and political good sense [2].

In the 21st century, major tourism practitioners have recognized the importance of the high value-added culture industry [7]. They are making efforts to change the traditional cultures of local area tourism resources and to develop related areas into a strategic industry [8]. With the advent of full-scale local autonomy, provinces and metropolitan cities in South Korea (Korea hereafter) have recently promoted various cultural tourism events that were traditionally operated by the Korean Central Government. Citizens are becoming more aware that the development of local cultures and local tourist industries leads directly to the development of the nation's overall culture and tourism [9]. Unfortunately, even though some world-class cultural tourism events have been developed and held in Korea, the reality is that foreign tourist participation in such events has not been as great as expected [10]. This is contrary to the country's aim of promoting global tourism through local cultural festivals [11].

Since local autonomy was launched in 1995 in Korea, many cultural tourism events have been developed in the country, many of which have been successful with positive effects on local economic, social, and cultural development. However, many provinces have competed with each other far too aggressively and have seemed to ignore the pure functions of those festivals, generating conflict with residents [12]. Furthermore, because many of them have had similar themes there have been problems, such as overlapping investments and wastage of funds by producing repetitive, rather than unique, local cultural events. Therefore, there is a need to reconstruct the cultural tourism industry in Korea, particularly in local cultural festivals in the country [10].

A local festival is the most typical local cultural event in Korea; however, more than $70 \%$ of these festivals do not have specific aims and themes. Most of them do not have a long cultural history, having been developed since local autonomy. The most significant problems for these events are the issues of timing, venue, and the uniqueness of the program. First, the timing of festivals has been decided mainly for the convenience of local authorities: more than 70\% of the festivals are held in September and October [11]. They are generally driven by government agencies and have simply replaced the old government-run events.

Second, with respect to the venues, more than $90 \%$ are playgrounds, parks, riverside highlands, and civic halls, which do not respect the uniqueness and characteristics of each local festival. More than $85 \%$ of local festivals have a public agency as their main stakeholder [11]. Finally, each local festival includes different kinds of typical national folklore events that do not necessarily represent local identities or culture. Therefore, the motivation for the local cultural events is conventional and homogenous: they are usually a succession of local cultural, traditional folklore representations of people in harmony driven by local government [13].

In contrast, the events should be held in a sacred venue, creating a separation from routine life to attract people through their curiosity, sacredness, and unique local motivation [14]. The local festivals can be competitive, attractive, and sustainable when their original meaning is preserved within their own authentic culture and theme [15]. Most events in Korea are provided for their own sake, and the timing is concentrated in the crowded peak seasons. They are plagued by unprofessional staff and frequent changes of responsible personnel. The route for participation of local community residents is often blocked by the over-control of public sector agencies.

This paper investigates the inaugural stage, operating process, main activities of stakeholders, distinctive backgrounds, and situations, and analyzes the outcomes of a local cultural festival in Korea to learn what the main factors and catalysts are that lead to success for a festival such as this one. It presents information on what type of preconditions and intangible infrastructure should be facilitated to make a local grassroots festival successful and sustainably developed over the years. The paper, as a case report, discusses several pivotal theoretical principles including social capital, community attachment, 
and community-based tourism development, before providing valuable implications and recommendations for local festival practitioners.

\section{Literature Review}

\subsection{Contribution of Festivals to Local Community Development}

In the study of tourism destination planning and marketing, festivals can play a diverse range of significant roles mainly as tourist attractions, image developers, destination branding creators, and maintainers of local heritage and culture [14]. They can also contribute to overcoming seasonality, accelerating other developments, enhancing visitor experience, and extending overnight stays [2]. They can also be understood as part of alternative tourism, fostering regional sustainable development, and strengthening hostguest relations [1,9]. Many festivals successfully attract not only local people but also visitors from outside the region and from foreign countries [10]. This understanding stresses that festivals are tourist attractions by themselves and that they contribute to overall destination attractiveness and competitiveness.

A tourist destination's image is one of the most important strategic tools for creating and sustaining tourism in the region or country [16]. Festivals are often developed as a vehicle to promote the image of a destination as an interesting and exciting place to visit that has more than just natural or cultural resources [14]. The quality of life of local residents can be enhanced by the hosting of successful festivals. Successful festivals can also animate urban redevelopment, and uplift and improve tourism infrastructure [8]. While understanding that the potential for festivals might not always be possible, nevertheless, the potential can be perceived as too high to ignore [17]. This supports the argument that festivals are effective catalysts for solidifying local development and fostering urban regeneration.

\subsection{Social Capital}

Social capital influences the discussion on social sustainability [18]. As a conceptual tool for examining the sociocultural interactions and processes associated with tourism, Jones [19] applied the concept of social capital to investigate the social change surrounding the formation of community-based tourism. Other researchers have also explored the role of social capital in determining tourism companies [20] and its importance in developing grassroots cultural tourism initiatives [21]. McGehee et al. (2010) examined the relationship between the length of residence of tourism stakeholders and social capital, and they also scrutinized the relationships that exist between the existence of social capital and other types of capital to understand tourism development in rural areas.

Moscardo [22] discovered insightful links between hosting community tourism activities and social capital. These include community pride and shared values and local identity; stronger social bonding with family members and friends; and the development of different types of networks. Therefore, the positive sociocultural impacts of tourism development include cross-cultural communication, positive changes in values and traditions, and cultural exchanges that help to build harmonious relationships between different individuals and many groups. Meanwhile, Kim and Petrick [23] found that image enhancement and consolidation are the most significant positive impacts of community tourism development. In addition, socialization can be further developed by tourism coordination through the creation of valuable networks and associations to coordinate tourism activities within a community [18,19] (McGehee et al., 2010).

\subsection{Community Attachment}

Community attachment has been increasingly discussed in tourism studies, and it has also been explored in festival and special event studies in recent years. Festival visitor studies have largely focused on festival attendees from different cultural and socioeconomic groups. Identifying the characteristics of people from different groups is essential when designing festival themes, programs, and activities to enhance overall satisfaction, improve word-of-mouth, and raise revisit intentions [17] through meeting specific needs 
and satisfying visitors' expectations. Many festival-related studies have been undertaken to understand the important attributes making visitors revisit a festival [21]. Community attachment has been crucially applied in festival studies as a significant festival visitor characteristic, which provides an improved method for classifying visitors, particularly for cultural community festivals, to closely examine their future intentions [7].

Community attachment has been primarily understood as a state of positive solidarity between people and their place of residence [10]. The meaning of place attachment has been developed in respect of different sizes and types of social and geographical environments [24]. In this sense, researchers have made efforts to understand community attachment as it closely relates to community tourism development. Kim, Uysal, and Sirgy [25], by analyzing the difference between common attachment and community attachment, established three dimensions of attachment: identity, dependence, and social relationship.

The strong and positive relationship between community attachment and residents' attitudes toward tourism has been widely studied. Researchers have shown that the strong attachment to community found is often caused by a highly positive attitude to tourism development with foreseeable benefits for the community [20]. Meanwhile, residents who had a high community attachment sometimes had negative attitudes toward tourism. Nonetheless, it remains widely accepted in the tourism field that high community attachment leads to a positive attitude toward tourism development [3]. Tolkach and King [26] argued that community attachment positively influences support for community tourism development. Other studies have supported this position by suggesting that community attachment has a significant impact on general attitudes about community $[3,8]$.

\subsection{The Main Issues in Community-Based Tourism Development}

There are widely recognized principles for community-based tourism, as follows. (a) Community tourism should involve local residents, who should participate in decisionmaking and ownership. (b) The local community should receive a fair and transparent share of the profits from any tourism venture. (c) Tour operators should try to work with communities rather than working separately. Where communities have representative organizations, these should be consulted, and their decisions respected. (d) Tourism should be environmentally sustainable, and local people must benefit and be consulted if conservation projects are to work. (e) Tourism should support traditional cultures by showing respect for indigenous knowledge. (f) Operators should work with local people to minimize the harmful impact of tourism. (g) Tour operators should keep groups small to minimize their cultural and environmental impact. (h) Tour operators or guides should brief tourists on what to expect and on appropriate behavior before they arrive in a community. (i) Local people should be allowed to participate in tourism with dignity and self-respect. Finally, (j) people have the right to say no to tourism, and communities that reject tourism should be respected $[15,27]$.

Mitchell and Reid [28] proposed an insightful framework for community integration in tourism planning and management. The theory is that a tourism integration process for a given community should be linked to three critical parameters: (i) community awareness, (ii) community unity, and (iii) the power or control of relationships, both local and external. Awareness, unity, and power for a certain tourism sector comprise an integration triangle and form a necessary part of the community's rise to self-reliance and local control. These variables are principally endogenous (factors internal to the community), but they will also be influenced by the exogenous environment (factors outside the community).

The general problems for the festival industry regarding sustainable community involvement in Korea are: (i) the lack of a professional educational institute for the events industry; (ii) unclear motivations and overlapping themes for events; and (iii) the lack of responsibility by the main stakeholders. Notwithstanding these negative issues, local cultural events have great potential to contribute to the local economy and sociocultural benefits for all if they are operated with local resident interest and active participation, as 
can be seen in the Chuncheon case. Considering the problematic situations listed above, which are common across the country, the CPF is distinctive and outstanding for a number of reasons, and it delivers benchmarking messages to many similar festivals that are trying to be more sustainable and successful. This is why the CPF was selected for the current case report.

\section{Methodology}

A variety of secondary data for this study was collected by the authors from local newspapers and from government documents related to the past and current issues of the $\mathrm{CPF}$. These data were used to comprehend tourism and environmental transitions regarding political, economic, and sociocultural aspects of CPF for Chuncheon City. The authors of the present paper have also participated in person in the CPF in 2016 and 2019 to experience the real ambience of the CPF. Based on these secondary data, we constructed experimental activities as participants and asked some interesting questions to both CPF participants and organizing staff during the festival to comprehend the overall attitudes and operational level of the staff. Although no official interviews or distribution of questionnaires occurred, we were able to discover and confirm a number of important factors from the festival.

\section{Results and Findings}

\subsection{Background and Programs of the CPF}

Chuncheon is a city with a population of just under 300,000 , located $100 \mathrm{~km}$ east of Seoul (population of 10 million), the largest and the capital city of South Korea (Korea hereafter). There are four lakes created by dams in Chuncheon, and the catchphrase of being a "lakeside city" has been put forward for decades. It has rivers, dams, lakes, an island, and mountains, which has meant that it is nicknamed "a romantic city with all kinds of leisure available in a beautiful landscape". The city is also the capital city of Gangwon Province.

The city faced financial difficulties managing the Children's Hall in 1989. The City then entrusted the management of the Hall to a local entrepreneur, Barunson Co. (a fancy stationery manufacturing and chain store company). The private company developed various cultural art programs to operate the Hall efficiently with the proactive help of local community residents. Several local academics and puppet industry professionals proposed to the company and local community leaders the hosting of a puppet festival. After a series of debates and tug-of-wars between the main stakeholders, the offer was finally accepted, an executive committee was composed, and the initial planning was set up and implemented in 1989 [29].

In 1995, the CPF was selected and officially awarded as one of the ten excellent regional festivals designated by the Ministry of Culture (of Korea) out of more than 1000 competitors. This award brought massive nationwide attention to the festival and dramatically lifted its profile. It is the largest puppet festival in Korea, with ten foreign puppet theater companies, 50 domestic professional puppet theater companies, and 20 domestic amateur puppet theater companies participating every year. In May 2001, the first puppet theater in Korea, the Chuncheon Puppet Theater, was built. In August 2001, it was approved to hold the Chuncheon Puppet Theater Festival, and in December of the same year, it was designated as a specialized art corporation (non-profit culture and arts corporation) [29].

The CPF in Korea is regarded as a Mecca for puppetry. It is one of the most renowned puppet performance festivals in the world. Its facilities, such as the Chuncheon Puppet Theater (opened in 2001) and the Chuncheon Puppet Museum (established in 2004), are considered state-of-the-art pioneers in showcasing various events as well as puppet shows. The Chuncheon Puppet Theater is the largest puppet theater in the country with a main performance hall (497 seats), open air performance hall (200 seats), and tent performance stages. Figure 1 shows the entrance of the theater during the festival in 2006. 


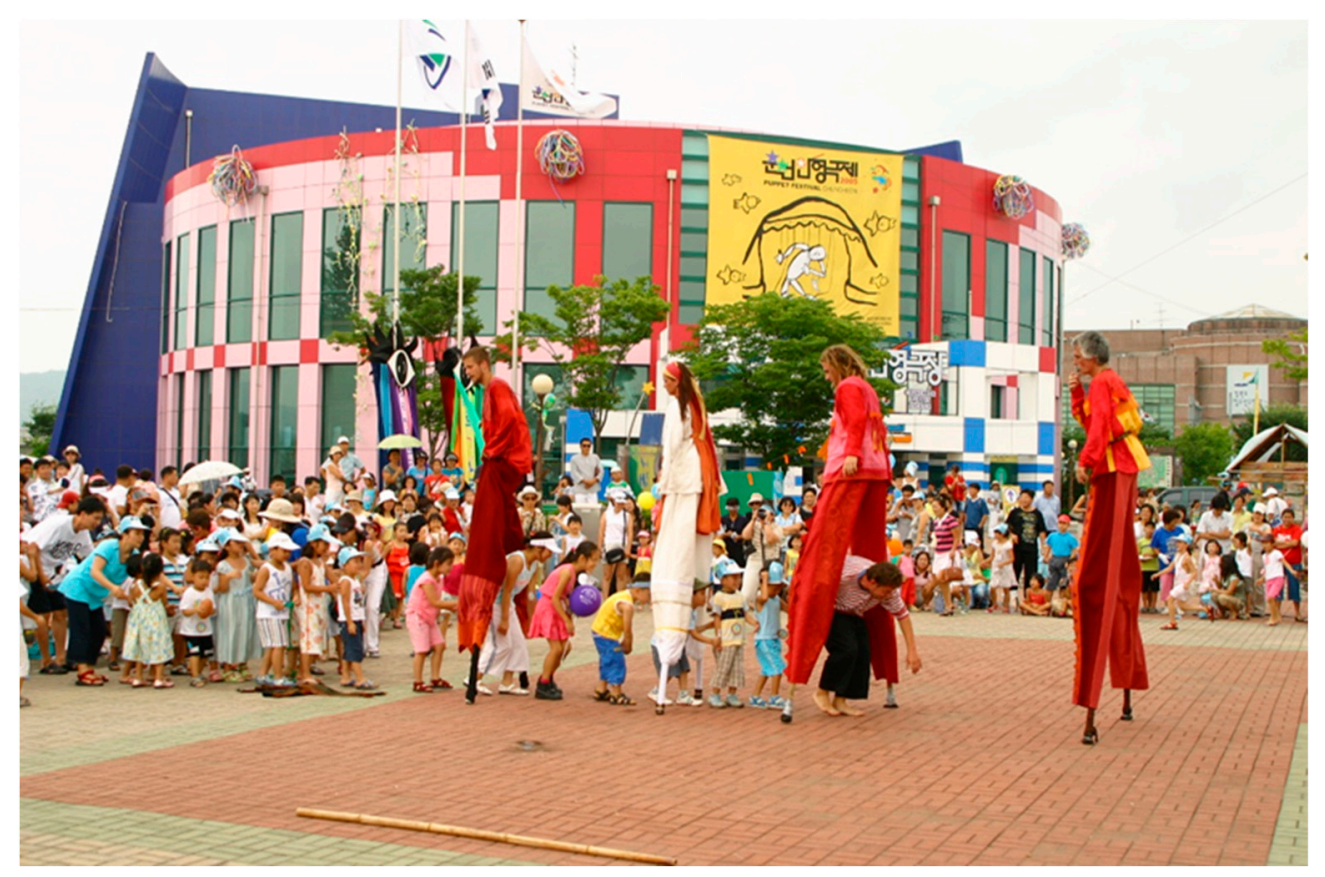

Figure 1. An outdoor performance during the festival.

The CPF event begins with an opening parade, a one-day program where children can experience the entire process from making a puppet show to stage performance, including celebration performances, performances by domestic and foreign puppet theater companies, a lightning puppet show, an amateur puppet show contest, a puppet theater script contest, a parade award, and a puppet show highlight. There is also a puppet theater workshop, a doll workshop, doll exhibitions, mural painting, children's book exhibition, face painting, and a local street doll exhibition. The Puppet Theater Workshop is a specialized course to learn how to make puppets using various professional materials.

\subsection{Unique Factors of the Sustainable Success of the CPF}

The CPF has since become a successful international puppet festival event that is held every year. There are several distinctive characteristics of the festival. First, rather than being managed by the government agencies of the city of Chuncheon, it is planned, operated, managed, and financed by the residents of the city along with a local entrepreneur. This involvement has been maintained and encouraged with several hundred volunteers from the local high schools and colleges every year helping run the festival. Second, it has maintained the single genre of a cultural art festival with puppet performances that are based on modern cultural art. It is different from other local festivals that lack such unique figures.

Third, it has helped children to undergo an interesting cultural experience in the local environment and has been aimed at developing a puppet show that is different from other festivals, which focus mainly on commercial profits. The festival is planned to remain a cultural event especially for children, with its motto "Dream for children, love for all". Fourth, the main stakeholders of the festival, who have professional knowledge and affection for puppets, have not changed since it was launched in 1989. Thus, the basic characteristics of the festival have been maintained. This is different from many other festivals in the country that have been discontinued due to serious discord and conflicts. Fifth, it is hosted every August, which is an off-season for festivals in Korea. This was decided by the community and has been highly successful because it is a school holiday season in the country.

Sixth, there has been consistent, proactive, and supportive participation from the local community, especially from the many young volunteers from local areas who have a strong pride and affection for the local area and its development. Seventh, there are systematic 
activities for effective marketing and promotion both from local community residents and government sector staff to large markets. Finally, it has become a model of a successful local festival and has demonstrated that a center for culture can be decentralized from the capital city area of Seoul.

The success factors can be summarized as: (i) steady financial support from a local entrepreneur who has a strong local affection; (ii) unique and consistent theme of the festival; (iii) providing a goodwill value for local residents rather than focusing on commercial interests; (iv) consistent stakeholder participation with professionalism; (v) attractive and affordable timing of the event; (vi) strong supportive involvement from volunteers; (vii) well-organized holistic marketing plans and activities; and (viii) providing strong "localism", which is decentralized from central government.

In 1989, the CPF had less than 100 participants from 14 local performance groups at only one venue (the Children's Hall). These numbers had increased by 2006 to more than 1000 professional participants from seven overseas theater companies, 40 local performance groups, and 31 amateur theater groups at more than ten venues around Chuncheon City. Almost every year since 2002, more than 100,000 visitors have come to Chuncheon, a city with a population of less than 300,000 , during the festival. Table 1 shows how the festival has grown from 1989 to 2019.

Table 1. Main statistics of the Chuncheon Puppet Festival (CPF).

\begin{tabular}{|c|c|c|c|c|}
\hline Year & $\begin{array}{l}\text { Number of Performing } \\
\text { Companies }\end{array}$ & $\begin{array}{c}\text { Number of } \\
\text { Performed Shows }\end{array}$ & $\begin{array}{c}\text { Length of } \\
\text { Festival in Days }\end{array}$ & $\begin{array}{c}\text { Total Number } \\
\text { of Attendees }\end{array}$ \\
\hline 1989 & 15 & 40 & 4 & 7500 \\
\hline 1990 & 23 & 63 & 5 & 10,000 \\
\hline 1991 & 33 & 64 & 5 & 16,500 \\
\hline 1992 & 39 & 64 & 5 & 16,500 \\
\hline 1993 & 43 & 68 & 5 & 23,500 \\
\hline 1994 & 51 & 68 & 5 & 23,107 \\
\hline 1995 & 53 & 71 & 5 & 44,523 \\
\hline 1996 & 60 & 110 & 5 & 56,867 \\
\hline 1997 & 61 & 117 & 5 & 55,600 \\
\hline 1998 & 67 & 121 & 5 & 54,265 \\
\hline 1999 & 65 & 148 & 5 & 54,942 \\
\hline 2000 & 67 & 149 & 6 & 80,973 \\
\hline 2001 & 64 & 235 & 7 & 91,528 \\
\hline 2002 & 65 & 172 & 8 & 107,743 \\
\hline 2003 & 79 & 240 & 10 & 124,000 \\
\hline 2004 & 72 & 226 & 10 & 130,500 \\
\hline 2005 & 76 & 200 & 7 & 101,413 \\
\hline 2006 & 77 & 215 & 7 & 101,177 \\
\hline 2007 & 69 & 199 & 7 & 88,000 \\
\hline 2008 & 87 & 216 & 7 & 85,030 \\
\hline 2009 & 79 & 177 & 7 & 103,500 \\
\hline 2010 & 80 & 189 & 7 & 101,000 \\
\hline 2011 & 76 & 170 & 8 & 86,000 \\
\hline 2012 & 75 & 150 & 8 & 166,500 \\
\hline 2013 & 113 & 210 & 8 & 175,000 \\
\hline 2014 & 67 & 149 & 8 & 120,000 \\
\hline 2015 & 74 & 199 & 8 & 136,000 \\
\hline 2016 & 58 & 97 & 4 & 55,000 \\
\hline 2017 & 61 & 120 & 8 & 110,000 \\
\hline 2018 & 58 & 110 & 8 & 120,000 \\
\hline 2019 & 42 & 73 & 8 & 132,000 \\
\hline
\end{tabular}

Source: The Chuncheon Puppet Festival Organizing Committee [29].

\subsection{The Emotional and Social Gains of Chuncheon Residents Derived from the CPF}

Chuncheon is located near the most populous areas in Korea on the upper stream of the Han River (the longest and largest river in the country); this has kept it from being 
industrialized by large-scale factories. Therefore, the Chuncheon residents have long felt discriminated against because their region has remained isolated and underdeveloped for centuries. However, now they have a strong pride as residents of Korea's proto-typical cultural city, mainly because of the CPF. This was confirmed by a nationwide survey by the Korean Government in 2018. When the residents were asked what the best strategic direction for Chuncheon City in the future would be, $34.7 \%$ answered as a culture/artoriented city, in comparison with a sophisticated industry-focused city $(17.8 \%)$, and a tourism-focused city (15.7\%).

This strong local pride and cultural consciousness derives from the series of cultural events initiated by the CPF. There are four international performing cultural festivals in Chuncheon that are hosted annually: the Mime Festival, the Animation Festival, the Chuncheon International Theatrical Festival, and the Puppet Festival. Educational institutes have been opened in recent years, including the Puppet Theme Park, the Puppet Play sample market, and the Puppet Academy. Several different sized public performance halls have been opened; Chuncheon now has the highest level in the country of population-to-seats in performing theaters. The Ministry of Culture and Tourism in Korea designated Chuncheon as an official city of culture in 1995 on the basis of the successful achievements of the CPF.

Chuncheon residents have escaped from the defeatism of the past as an isolated region lacking local development. There are "new" residents in the city that initially came to Chuncheon as professionals or students of cultural events. Many of them work as operating staff in related events, with ordinary citizens serving as voluntary staff-with the highest volunteer rate in Korea. Chuncheon is an example of successful community participation with a high rate of volunteering that helps increase local competitiveness and local innovation.

There have been diverse sociocultural effects resulting from the success of the CPF. These include the following: the CPF (a) improves the local image of Chuncheon City; (b) enhances the affection of the local residents; (c) promotes local cultural art; (d) improves the quality of life through the local residents' participation in high-profile cultural event activities; (e) protects and strengthens the local cultural resources; and (f) promotes cultural exchange between regions and countries. By hosting a cultural art festival, the festival not only facilitates cultural exchange but also helps the event to keep developing and evolving, thereby investing in its own longevity. Many cultural art stakeholders from other regions have participated in the $\mathrm{CPF}$, consequently contributing to the spread of the puppet show and human resource exchange. As a result, professional puppet show personnel have been trained and educated in the local Chuncheon area.

\subsection{Associated Activities and Programs}

The CPF has also hosted the Puppet Theater Market since 1999, which efficiently connects supply (performing companies) and demand (groups who want performances) in the puppet performance industry. With its meticulously prepared parade at the opening ceremony, the CPF has offered a great opportunity to appreciate a variety of unique presentations, such as invited performances, general participation, free participation, and street performances.

One of the well-developed associated events thanks to the success of the CPF is the Chuncheon International Mime Festival (CIMF). It started as the "Korean Mime Festival" with the theme of (panto)mime (mime: silent clown play) in 1989, but it changed to "Chuncheon Mime Festival" in 1995 when overseas mime teams were invited. Since 2000, various events have been prepared and the scale of the event has been rapidly expanded. To popularize mime art, numerous domestic and foreign performing artists, performance artists, and exhibition artists are participating in the CIMF. A variety of forms and spaces have been tried that transcend the barriers between existing genres while taking the theme of mime. The Chuncheon Mime Festival Steering Committee is annually hosting the event. In addition to presenting various forms and contents of Korean mime, it has expanded to an international cultural event by inviting many overseas mime teams. 


\section{Conclusions, Implications, and Suggestions}

\subsection{Discussion}

Cultural festivals and community fairs add vitality and enhance the tourist appeal of a destination [7]. Cultural festivals and events can become the quintessence of a region and its people [5]. Carlson [30] provides an interesting analysis of the significance of performance in cultural events. He argues that performance implies not just doing things, but selfconsciousness about doing and re-doing, on the part of both performers and spectators. He continues by saying that performers and audience alike accept that a primary function of this performing activity is strongly cultural, as an exploration of the self and other, of the world as experienced, and of alternative possibilities.

Community involvement in tourism planning and development can result in a shared vision, and by focusing on the community's heritage and culture in the development of the tourism product, destination distinctiveness can be created [31]. Residents who concur with tourism goals set for their region will be equally happy with the outcomes that ensue, which in turn helps to achieve sustainable tourism and a sense of place [32]. As for sociocultural measures, perceptions and attitudes towards the local tourism industry and perceived community or individual participation should be enhanced with community integration. The attitudinal responses of residents, industry players, and tourists alike for a given destination area can be assessed over time.

Local cultural events can be attractive tourism resources when there is strong harmony between the visitors, the event organisers, the tangible products, and the local community (residents) that benefit from the sociocultural effects. The tangible products are composed of festivals, event programs, entire event packages, and tangible merchandise that are available during the events. Local uniqueness needs to be secured for cultural art events to successfully develop as tourist attractions. There also should be a logical and scrupulous preparation in the design, implementation, operation, and support systems. Unfortunately, the financial support for local events from the central and provincial governments has previously been applied over too many small events across Korea, giving each only a limited budget.

There are more than 1000 registered local festivals in Korea, mostly held annually. However, most of the Korean local festivals have been suffering from a number of problems in the last couple of decades. First, regional governments have tried to use local festivals as a tool to access funds from central or provincial governments. So, the festival planners and promotors are mainly public sector staff without much professional knowledge or shared visions of each festival. They often make haste to initiate a festival without sufficient justification or planning. Local residents are not well aware of the festival itself, nor the stakeholders and programs. In the worst case, some of the mayors of regional cities merely focus on inaugurating or hosting a festival during their incumbency to show off hosting a festival as their administrative achievement, and they use festivals held in their local areas when they run for election as a parliament member or in regional government. So, sometimes a local festival is treated as a show window display item.

Second, most of the festival organizers focus on congregating as many people as they can, and that results in most festivals looking like a local marketplace where everyone can attend but crowded with many different types of merchants who sell common and miscellaneous goods that are not related to the main theme of the festival at all. This makes most festivals look homogenous without unique or sustainable attractions. Third, local community residents are not very respected or invited into the planning process in operating festivals. This causes indifference, and residents feel isolated and abandoned from the event. As the disposable income keeps growing and people's interests and curiosity in certain festival items become more diverse and specified, the expectation level of potential festival participants is growing in Korea. However, festival managers are not catching up with this trend. Also, there are more reasons such as lack of professionalism in the festival, internal struggles for vested rights, politically affected programs, inconsistent budgets, and a lack of transparency and unique themes in operation. 


\subsection{Implications and Recommendations for the CPF}

This report provides a useful case study of the Chuncheon Puppet Festival in Korea, which is a valuable and significant event that exemplifies how a local festival can be developed as one of the sustainable tools to contribute to a local destination over the long term. However, although the CPF has been recognized as a successful local event in Korea, there are still several tasks required to improve the festival as a purely local community festival: (a) there should be more exchange of human resources among the festival executive members, community associations, and the Chuncheon Civic Government; (b) the local Chuncheon residents should have more control over the festival operation and programs; and (c) a local cultural trust should be established by cultural art professionals, local resident organizations, puppet show professionals, and public agency staff.

There are conditions that need to be met to achieve these tasks for the CPF. First, complete financial security and independence is required. The budget for the cultural sector needs expanding to help Chuncheon maintain its reputation as "the cultural city". Partial profit-creating programs need to be designed, and the operating fund of the puppet show can be considered throughout the whole year. All kinds of souvenirs should be made and commercialized, celebrity puppets should be manufactured and sold, royalty income from character-making should not be overlooked, and a diverse route for distribution of tickets needs to be developed.

Secondly, the cultural infrastructure should be improved and expanded. Here, efficient linkages with other cultural fields, especially those attractive and educational to children, need to be further developed. The adjacent tourist sites, cultural relics, restaurants, accommodations, entertainment facilities, and accessible roads should be improved for the mutual benefit of all stakeholders in the puppet festival. Thirdly, the CPF has strong potential to attract foreign participants, especially those who have young children. To achieve this, the festival organizers need to pay much more attention to promoting the event in major foreign languages, providing more interpreting services during the event, hiring more foreign staff, and providing a global participation program so that more foreign participants can comfortably enjoy the event, and in doing this they can spread positive word-of-mouth to their global associates. The public sector staff should also take this matter seriously in cooperating with the private sector.

\subsection{Managerial Recommendations for General Festival Operators}

As lessons learned from the $\mathrm{CPF}$, there are requirements and suggestions for local cultural events to steadily improve the economic, social, and cultural sustainable effects in local areas in Korea and other countries in similar situations. Firstly, the local community and private sector should be the leading stakeholders in local events, with public agencies mainly needing to focus on a supporting role. In the first place, local festivals should be designed, celebrated, and enjoyed by locals. Tourists tend to visit local events when the local community residents participate and enjoy them first.

Secondly, there should be financial independence at the local community level. Various profit-creating businesses closely linked to the event need to be developed. Local entrepreneurs prefer to invest their funds in local events in which the residents have an interest and enjoy. Thirdly, regular cultural festivals and associated programs in local areas need to be provided throughout the year. The all-year-long performance hall could be one of the ideal infrastructures for this. Fourthly, back-up facilities and products for tourism development should be associated with restaurants, historical cultural relics, and accommodations, as well as entertainment facilities. Finally, the main theme of the festival should be consistent, unique, and entertaining to sustainably attract target markets.

\subsection{Limitations and Further Research}

This study is a case report that explores the subject matter by reflecting on secondary data, and by observing a festival in Korea. The CPF could be further investigated and compared with other festivals in other countries that have similar characteristics and 
development backgrounds for comparative research. For deeper and closer investigation, in-depth interviews with experts and key stakeholders or the distribution of questionnaires to festival participants could add more value to investigate how local festivals can be improved in future studies.

Author Contributions: Conceptualization, X.L. and J.S.K.; methodology, X.L.; validation, T.J.L.; formal analysis, X.L.; investigation, J.S.K.; resources, X.L.; data curation, J.S.K.; writing—original draft preparation, X.L.; writing—review and editing, T.J.L.; supervision, T.J.L.; project administration, J.S.K.; funding acquisition, X.L. and J.S.K. All authors have read and agreed to the published version of the manuscript.

Funding: This paper was supported by the Center of Humanities \& Social Science Fund of Guangxi Autonomous Region (Grant number: ZX2017001) and Guangxi Philosophy and Social Science Planning Office (Grant number: 18BMZ007) in China. This paper was supported by the Sehan University Research Fund in 2021 (Grant number: sh2094).

Institutional Review Board Statement: The study was conducted according to the guidelines of the Declaration of Helsinki and approved by the Institutional Review Board of the Guangxi Normal University (26 April 2021).

Informed Consent Statement: Informed consent was obtained from all subjects involved in the study.

Data Availability Statement: Data sharing not applicable.

Conflicts of Interest: The authors declare no conflict of interest. The funders had no role in the design of the study; in the collection, analyses, or interpretation of data; in the writing of the manuscript, or in the decision to publish the results.

\section{References}

1. Chang, K.-C.; Hsieh, T. From Having Fun to Applause: The Study of Relationships among Festival Benefits, Festival Identity and Festival Support by Viewpoints of the Hosts and Guests. Sustainability 2017, 9, 2240. [CrossRef]

2. Chen, X.; Yim, B.H.; Tuo, Z.; Zhou, L.; Liu, T.; Zhang, J.J. “One Event, One City”: Promoting the Loyalty of Marathon Runners to a Host City by Improving Event Service Quality. Sustainability 2021, 13, 3795. [CrossRef]

3. Zhang, Y.; Xiong, Y.; Lee, T.J.; Ye, M.; Nunkoo, R. Socio-Cultural Sustainability and the Formation of Social Capital from Community-based Tourism. J. Travel Res. 2021, 60, 656-669. [CrossRef]

4. Stone, L. Cultural Cross-roads of Community Participation in Development: A Case from Nepal. Hum. Organ. 1989, 48, 206-213. [CrossRef]

5. Zarębski, P.; Zwęglińska-Gałecka, D. Mapping the Food Festivals and Sustainable Capitals: Evidence from Poland. Sustainability 2020, 12, 10283. [CrossRef]

6. Sun, H.; Wu, S.; Li, Y.; Dai, G. Tourist-to-Tourist Interaction at Festivals: A Grounded Theory Approach. Sustainability 2019, 11, 4030. [CrossRef]

7. Rastrollo-Horrillo, M.-A.; Navarrete, L. Evaluation Model of the Roles of Festivals in the Internationalization of Performing Arts: Evidence from Flamenco Festivals. Sustainability 2020, 12, 10405. [CrossRef]

8. Tölkes, C.; Butzmann, E. Motivating Pro-Sustainable Behavior: The Potential of Green Events: A Case-Study from the Munich Streetlife Festival. Sustainability 2018, 10, 3731. [CrossRef]

9. Sohn, H.K.; Lee, T.J.; Yoon, Y. Relationship between Perceived Risk, Evaluation, Satisfaction, and Behavioral Intention: A Case of Local Festival Visitors. J. Travel Tour. Mark. 2016, 33, 28-45. [CrossRef]

10. Lee, I.S.; Lee, T.J.; Arcodia, C. The Effect of Community Attachment on Cultural Festival Visitors' Satisfaction and Future Intentions. Curr. Issues Tour. 2014, 17, 800-812. [CrossRef]

11. Ministry of Culture, Sports and Tourism. Annual Report on Tourism Trends in Korea; Ministry of Culture, Sports and Tourism: Seoul, Korea, 2020.

12. Gannon, M.; Rasoolimanesh, S.M.; Taheri, B. Assessing the Mediating Role of Residents' Perceptions toward Tourism Development. J. Travel Res. 2021, 60, 149-171. [CrossRef]

13. Wickham, M.; Donnelly, T.; French, L. Strategic Sustainability Management in the Event Sector. Event Manag. 2021, 25, $279-296$. [CrossRef]

14. Oh, M.J.; Lee, T.J. How Festivals Affect the Destination Choice of Tourists. Event Manag. 2012, 16, 1-9. [CrossRef]

15. Lai, H.K.; Pinto, P.; Pintassilgo, P. Quality of Life and Emotional Solidarity in Residents' Attitudes toward Tourists: The Case of Macau. J. Travel Res. 2021, 60, 1123-1139. [CrossRef]

16. Park, H.J.; Lee, T.J. Influence of the 'Slow City' Brand Association on the Behavioural Intention of Potential Tourists. Curr. Issues Tour. 2019, 22, 1405-1422. [CrossRef] 
17. Yoo, I.Y.; Lee, T.J.; Lee, C.K. Effect of health and wellness values on festival visit motivation. Asia Pac. J. Tour. Res. 2015, 20, 152-170. [CrossRef]

18. McGehee, N.G.; Lee, S.; O’Bannon, T.L.; Perdue, R.R. Tourism-related Social Capital and Its Relationship with Other Forms of Capital: An Exploratory Study. J. Travel Res. 2010, 49, 486-500. [CrossRef]

19. Jones, S. Community-Based Ecotourism: The Significance of Social Capital. Ann. Tour. Res. 2005, 32, 303-324. [CrossRef]

20. Xu, Q.; Perkins, D.D.; Chow, J.C.C. Sense of Community, Neighboring, and Social Capital as Predictors of Local Political Participation in China. Am. J. Community Psychol. 2010, 45, 259-271. [CrossRef]

21. Kim, S.R.; Youn, S.H.; Um, S.H.; Lee, T.J. The Mediation of Information Technology on Visitors' Experience at a Cultural Heritage Site. Asia Pac. J. Tour. Res. 2016, 21, 1126-1141. [CrossRef]

22. Moscardo, G. Building Community Capacity for Tourism Development; CAB International: Wallingford, UK, 2008.

23. Kim, S.; Petrick, J.F. Residents' Perception on Impacts of the FIFA 2002 World Cup: The Case of Seoul as a Host City. Tour. Manag. 2005, 26, 25-38. [CrossRef]

24. Zhang, Y.; Shi, K.-X.; Lee, T.J. Chinese Girlfriend Getaway Tourism in Buddhist Destinations: Towards the Construction of a Gendered Spirituality Dimension. Int. J. Tour. Res. 2021, 23, 1-12. [CrossRef]

25. Kim, K.; Uysal, M.; Sirgy, M.J. How does Tourism in a Community Impact the Quality of Life of Community Residents? Tour. Manag. 2013, 36, 527-540. [CrossRef]

26. Tolkach, D.; King, B. Strengthening Community-based Tourism in a New Resource-based Island Nation: Why and How? Tour. Manag. 2015, 48, 386-398. [CrossRef]

27. Mann, M. The Community Tourism Guide; Earthscan: Kent, UK, 2000.

28. Mitchell, R.E.; Reid, D.G. Community Integration: Island Tourism in Peru. Ann. Tour. Res. 2001, 28, 113-139. [CrossRef]

29. The Chuncheon Puppet Festival Organizing Committee (Chuncheon, Korea). Personal communication, 2021.

30. Carlson, M. Performance: A Critical Introduction; Routledge: London, UK, 1996.

31. Jani, D. Local Attendees' Perceptions of Festival Impacts: A Factor-cluster Analysis Approach to the Zanzibar International Film Festival. J. Conv. Event Tour. 2017, 18, 301-317. [CrossRef]

32. McCartney, G.; Leong, V.M.W. An Examination of the Impact of Green Impressions by Delegates toward a Trade Show. J. Conv. Event Tour. 2018, 19, 25-43. [CrossRef] 